Portland State University

PDXScholar

1972

\title{
Behavioral characteristics associated with accidental poisoning in childhood
}

\author{
Nancy Koroloff \\ Portland State University \\ Emily Tufts \\ Portland State University
}

Follow this and additional works at: https://pdxscholar.library.pdx.edu/open_access_etds

Part of the Social Work Commons

Let us know how access to this document benefits you.

\section{Recommended Citation}

Koroloff, Nancy and Tufts, Emily, "Behavioral characteristics associated with accidental poisoning in childhood" (1972). Dissertations and Theses. Paper 1673.

https://doi.org/10.15760/etd.1672

This Thesis is brought to you for free and open access. It has been accepted for inclusion in Dissertations and Theses by an authorized administrator of PDXScholar. Please contact us if we can make this document more accessible: pdxscholar@pdx.edu. 
BEHAVIORAL CHARACTERISTICS ASSOCIATED WITH

ACCIDENTAL POISONING IN CHILDHOOD

\author{
oy \\ Nency Koroloff \\ Emily Tufts M.D.
}

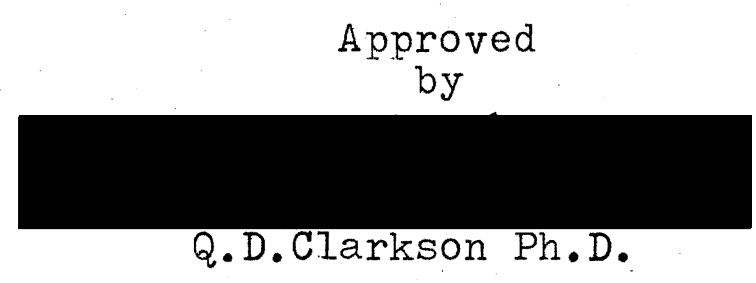

A report submitted in partial fulfillment of the requirements for the degree of

Waster of

Social Work

Portland State University

1972

\title{
PORTLAND STATE UHIVERSITY LIBRARY
}




\section{ABSTRACT}

Two groups of parents from different socio-economic levels were questioned about the behavioral characteristics of their children before 18 months and subsequent incidences of accidental poisoning. The data collected showed proportional numbers of accidental poisonings regardless of parent education, race or income. Jnusual activity in the child before 18 months was the best predictor of accidental poisoning during childnood. 


\section{BEHAVIORAI CHARACTERTSTICS ASSOCIATED WITH ACCIDENTAL POISONING IN CHILDHOOD}

Accidental poisoning of young children by household agents and drugs is still one of the leading problems in the field of pediatrics. In $1969,76,155$ cases of poisonings in children under age five were reported ${ }^{1}$. The seriousness of the problem has given rise to many studies, most of which, until recently, have indicated inadequate parental supervision and the accessibility of the poison as major factors. Current research suggests that personality characteristics and emotional environment, combine in a complex way, to produce a child who is temperamentally more inclined toward accidental poisoning.

\section{Survey of the Literature}

Jacobziner ${ }^{2}$ concluded that most poisonings were due to carelessness on the part of the parent and poor choice of storage place. In $1966^{3}$ he found that poisoning-incidence was higher in lower class and non-white areas. Seventy per cent of the children in his sample were characterized as active and curious.

Baltimore and reyer ${ }^{4}$ found children who had been poisoned to be more daring but not nore impulsive or active. They found no difference in accident proneness between poisoned and non-poisoned children. However, exaggerated oral tendencies 
were described almost twice as often for the poisoned children. Their study found no difference in the number or pattern of storage of potentially toxic agents in the home, between poisoned and non-poisoned children.

Koumans ${ }^{5}$ found availability, easy accessibility and oral exploration as possible factors in poisoning incidents. He postulatca a "purposeful bohavior" behind the accidents. Sobel ${ }^{6}$ found that social class, religion, income, family size, accident pronencss, environmental hazard or lack of perental supervision djd not correlate with repeated episodes of poisoning in children. He also found that there was no correlation between the accessibility of poisons in a house and whether or not children in that house had been poisoned?

Stewrt ${ }^{\beta}$ in 1970 argued that hyperactive children were significantly more common in the whole poison group and among poisoned boys. In his study, mothers commonly reported that their hyperactive chjloren were very active in the crib, had fecding, sleep and general health problens significantly more than normal childron.

liethod

This paper presents the findings of two studies, the first done during the summer of 1970 predicted poisoning in children on the basis of behavioral indicators that could be applied to chiluren under 13 monthe: of age. The second study was a follow-up carried out in the spring of 1971 designed to verify the findings of the first study and to extend its scope. 
The 1970 study was an outgrowth of the Oregon Collaborative Perinatal Study. Under this study children have been followed for seven years starting at the time of the mothers first visit to the obstetrical clinic. The pregnancy and delivery were observed closely and the children followed according to a standard protocol. Of the 1500 children followed, 141 had been accidentally poisoned by tho time they were seven. Two proups of 82 children each were selected at random from the non-poisoned children to serve as controls. Sixty-six variables were chosen from the data collected on the children and their families. Because of computor limitations, stepwise discrininant analysie of the data was done in two parts, each part containing analysis of thirty three variables.

TABLE 1

Stewise discriminant analysis of variables $1-33$

step No. Varicble No. Variable Name

1212

$2 \cdot 13$

$3 \quad 21$

4.22

513
Unusual amount of activity reported at 12 months. Unusual amount of activity reported at 18 months. Amount of medication given by 18 months. Unusual amount of crying reported by 4 ronths. Amount of redication given by 4 months.

Steomise discriminant andysis of variables $36-66$

\begin{tabular}{|c|c|c|}
\hline 1 & 16 & $\begin{array}{l}\text { Defree of dependency at } \\
\text { t year psychological exam. }\end{array}$ \\
\hline$\frac{2}{3}$ & $\frac{9}{6}$ & $\begin{array}{l}\text { Mothers education } \\
\text { Activity level at } 8 \text { month }\end{array}$ \\
\hline , & 15 & $\begin{array}{l}\text { Degree of cooperation at } \\
4 \text { year psycholofical exam. }\end{array}$ \\
\hline & 12 & WISC performance score. \\
\hline
\end{tabular}


Variables selected for this particular study pertained to physical abnormalities, Ieeding problems, degree of activity, injuries, crying, behavior profiles, intelligence or both mother and child, socio-economic factors and emotional problems. In the course of computing discriminant functions, the entire groun of children (one poisoned group and two control groups) were studied for each variable.

On the basis of discriminant functions computed from the oasic sixty-six variables we vere able to classify a child correctly as a poison risl $67 \%$ of the time and to classify a chila correctly as a non-poison risk $70 \%$ of the time. Those variables which stood out before the child was 18 months of age were unusual amount of activity, unusual amount of crying, and medications given. The mothers seemed to view the children who were later poison victims as less active than expected for that age. The psychologist judged their activity levels as above the mean for the sroup when the children were examined at 3 months. Fron this data we ieel that the child who is likely to be accidentally pojsoned during childhood can be identified in the first year of life.

The first study served to identify predictors of childhood poisoning in a sample made up predominately from the lower socio-economic class. This second study, done in the spring of 1971, was desisned to test the indicators over an upper and midale socio-economic class sample. Another objective was to test the iypotinesis that accidental poisoning of 
children does occur in families from all classes.

Data from the second study were obtained by attending the evenine parent meetings of 23 of the 25 cooperative preschools in the Portland Metropolitan area. During the meeting the parents were asked to fill out a questionnaire for each child under six years of age in their family.

Tile scope of the questionnaire covered questions about whether and how the child had been poisoned or injured, nedicine taken before 13 months, unusual type and amount of activity and crying before 13 months, feeding problems hefore 13 inonthe, mentel problems in the family, marital status of the fanily, occupation and education of both mother and father and income of the family.

Results

Seven hundred and twenty two children were studied of whom 95 had been poisoned at least once. This was 13\% of the total population compared with $9.4 \%$ in the first study. Eaucation was high for both mothers and fathers. Occupation. of the fathers tended to be either white collar or professional. The childiren who were poisoned were reported to have more unusual anount of activity than the non-poisoned group. 
TABLE 2

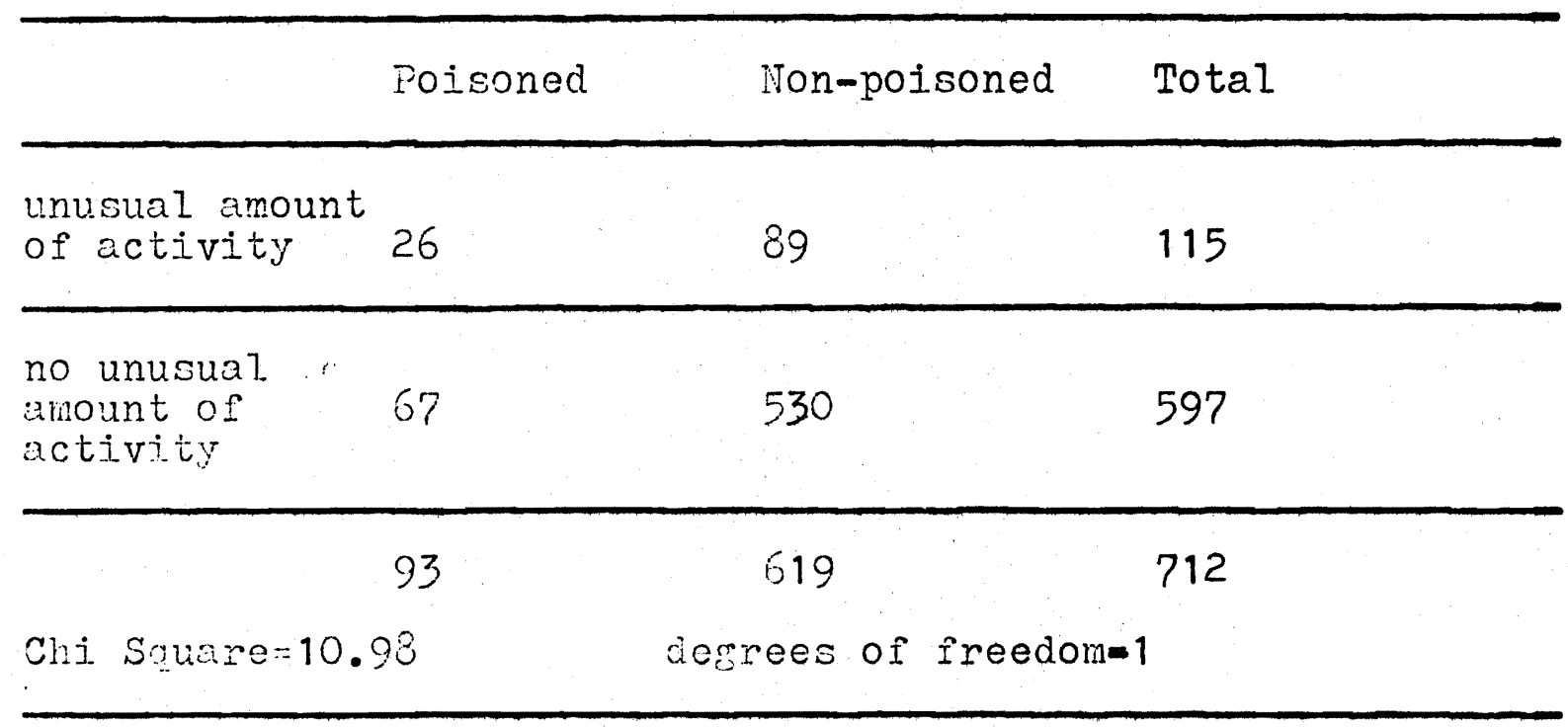

The poisoned sroup's mothers reported more unusual tynes of activity before their children were 18 months witi hosd banging and temper tantrums being reported more then for the non-poisoned children. Children who had poisoned themselves did not require significantly more medication before 18 inonths than did non-poisoned children nor did they seem to have more injuries before 18 months. The poisoned child was not reported to have cried more or less than the non-poisoned child. Mental or emotional nroblems were not significantly higher in the poisoned child's family.

Discussion

From these results it can be seen that socio-economic level has little or no bearing on whether or not a child is accidentally nojsoned. Neither race nor education of the 
parent were significant when controlled for economic class. Our first study and much of the literature points to over-activity in the infant as a predictor. Both of these studies sugeests that unusual amount of activity, whether over-activity or under-activity, is a good predictor of accidental poisonings. The first study indicated that mothers often saw their children as under-active while a psychologists who tested tho same babies at 8 months saw the child as over-active. This might suggest that neither the mother or the psychologist are an accurate judge of the childs level of activity and need some norm by which to compare it. In the second study, the mothers were being asked to give retrospective data that had to be recalled Irom up to six years previous. It is possible that some mothers recalled nore unusue? activity as a way of justifyine their child's accidental noisoning. In either case, more study is needed to quantify activity in an infant and to set un standards by which over, under and normal activity can be judged. The authors are currently working to perfect a time-observation technique of measuring activity in infants and young children. Further woris in the behavioral characteristics of children who poison themselves could then be based on these standards. 
Summary

We have established in this study that accidental poisoning is reported in the same proportion regardless of socio-economic level, race or education of the parents. We have also established that unusual amount of activity occurs more frequently in infants who will poison themselves in childhood. No other variable is significant in both studies or over both socio-economic classes. Further rescarch must be done to determine how best to identify and modify those infants who show the predictive activity levels. Of special interest will be the small group of infants who snow unusual activity before 18 months but do not get poisoned. What is (or is not) present in their environment may give us insight into the basis for more effective poison prevention prograns. 


\section{References Cited}

1 National Clearinghouse for Poison Control Centers Bulletin, sent-oct 1970, o5.

2 Jecobziner, H., "Causation, Prevention and Control of Accidental Poisonings", Journal of American Medical Association, $171: 1769-77,28$ Nov 59.

3 Jacobziner, H., "Accidental Poisoning in Children", Medical Times, 94:221-41, Feb 66.

4 Baltimore, C. Jr., Meyer, R.J., "A Study of Storage, Child Behavior Traits, and lother's Knowledge of Toxicology in 52 Poisoned Families and 52 Comparison Families", Pediatrics, 4.1 Sunpl:816-20, Nov 69.

5 Koumans, A.J.R., "A New Aspect of "Accidental" Poisoning in Chi.ldhood, An Approach to Prevention"., Pediatrics, 25:1067-70, June 60.

6 Sobel, R., Margolis, J.A., "Repetitive Poisonings in Children", Pediatrics, 35:641-51, Apr.65.

7 Sobel, R., "Traditional Safety Neasures and Accidental Poisoning in Childhood", Pediatrics, 44 Suppl:811-6, Nov 69.

2 Stewart, M.A., Thach, B.T., Freidin, MoR., "Accidental Poisonine and the Hyperactive Child Syndrome", Disease of the Hervous System, 31:4:03-7, June 70 . 